\title{
Explaining Interest Rate Spread In Namibia
}

\author{
Joel Hinaunye Eita, Monash University, South Africa
}

\begin{abstract}
This paper investigates the determinants of interest rate spread in Namibia for the period 1996 2010. The investigation is conducted through cointegrated vector autoregression (VAR) or multivariate cointegration methods. The investigation reveals that interest rate spread in Namibia is determined by Treasury bill rate, inflation rate, the size of the economy, financial deepening, bank rate or discount rate and exchange rate volatility. Treasury bill rate, inflation rate and bank rate are associated with an increase in interest rate spread. The size of the economy and financial deepening are associated with a decrease in interest rate spread. The results suggest that an increasing interest rate policy pursued by the government can cause interest rate spread to rise. Increase in the cost of funds to commercial banks may be passed to consumers in the form of higher interest rate spread. An increase in the cost of doing business will cause interest rate spread to rise. Interest rate spread can be reduced by increasing the size of the economy which allows for economies of scale and greater competition. Financial deepening, which allows a high level of interbank competition, can also reduce the interest rate spread.
\end{abstract}

Keywords: Interest Rate Spread; Financial Deepening; Financial Sector Efficiency; Namibia

\section{INTRODUCTION}

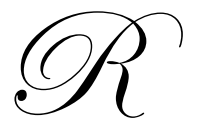

eforms in the financial sector have been important components of economic policies of many countries. According to the conventional wisdom, flexibility and efficiency of the financial system are crucial for the growth and development of the economy (McKinnon, 1973; Shaw, 1973; Chirwa and Mlachila, 2004). McKinnon (1973) and Shaw (1973) suggest that government intervention and control in the financial system should be discouraged because it disturbs the working of the market mechanisms. Too much government control and intervention in the economy can cause financial repression which will in turn decrease economic growth and development. There are many studies that investigated the relationship between financial deepening and economic growth. These studies (Levine, 1997; Jung, 1986; Calderon and Liu, 2003; Choe and Moosa, 1999) found a positive relationship between financial deepening and economic growth and these studies provide evidence in support of the postulation of McKinnon (1973) and Shaw (1973).

Financial liberalisation in many developing countries (mainly in Sub-Saharan Africa) started in the 1980's and it involved reduction and removal of in interest rate control. It also entailed new laws, institutional reforms and regulations that are governing the financial sector, as well as restructuring and privatisation of banks (Chirwa and Mlachila, 2004). These financial reforms were expected to increase financial sector efficiency to a level which is comparable to that of the developed world. This suggests that one of the important factors in economic growth and development is efficient financial intermediation. Efficient financial intermediation is important because it mobilises resources required for growth and development. This suggests that banks and other financial institutions play an important role in the growth and development of the economy. An important measure of efficient financial intermediation is interest rate spread. The interest rate, which is defined as the difference between lending and deposit rates, has important impact on growth and development. An increase in interest rate spread indicates that the banking sector is not efficient and also suggests that there are development challenges in the financial sector. Empirical studies, such as Randal (1998) and Barajar et al. (2000) on Latin America and Caribbean countries indicate that interest rate spreads remained high relative to those in developed countries, despite financial liberalisation. However, there was some evidence of decline in Colombia (Chirwa and Mlachila, 2004). This indicates that despite financial liberalisation, interest rate spread remained high in Latin America. Folawewo and 
Tennant (2008) also stated that interest rate spread in Africa, Latin America, and Caribbean countries is higher than in developed countries.

An efficient banking sector is beneficial to the economy because it allows higher expected return for savers that have a financial surplus and lowers the cost of borrowing for those who want to invest in new projects and need external finance (Folawewo and Tennant, 2008). This means that when the interest rate spread is high, potential savers can be discouraged because of low returns. This argument is supported by Ndung'u and Ngugi (2000) that a high interest rate spread decreases financing opportunities for potential borrowers, which means that since a higher interest rate spread shows that the cost of intermediating between borrowers and savers is rising, banks can only channel a smaller proportion of savings into productive investment. This can reduce lending which will, in turn, decrease investment and economic growth. This raises an important question - "What are the determinants of interest rate spread in an economy?"

Although there are many studies that looked at the determinants of interest rate spread in Latin American and African countries, empirical investigations on the determinants of interest rate spread in Namibia are limited. The knowledge about determinants of interest rate spread in Namibia is limited, which indicates that there is gap on the determinants of interest rate spread in Namibia. This paper contributes to the limited empirical evidence on the determinants of interest rate spreads in Namibia. Therefore, the purpose of this paper is to investigate the determinants of interest rate spread in Namibia.

\section{INTEREST RATE SPREAD IN NAMIBIA}

The trends of interest rate spread in Namibia for the period 1996-2010 are presented in Figure 1, which shows that Namibia experienced an average interest spread of 6\% during the period 1996-2010. The interest rate spread in Namibia is a major concern and is attributable to lack of competition in the banking sector. The banking sector in Namibia can be defined as an oligopolistic type of market structure. The sector is dominated by four commercial banks. Although the interest rate spread has been on a slight declining trend between 2004 and 2010, it is still above $4 \%$. The high interest rate spread suggests that the banking sector in Namibia is not efficient. Hence, it is important to determine factors that contribute to this higher interest rate spread.

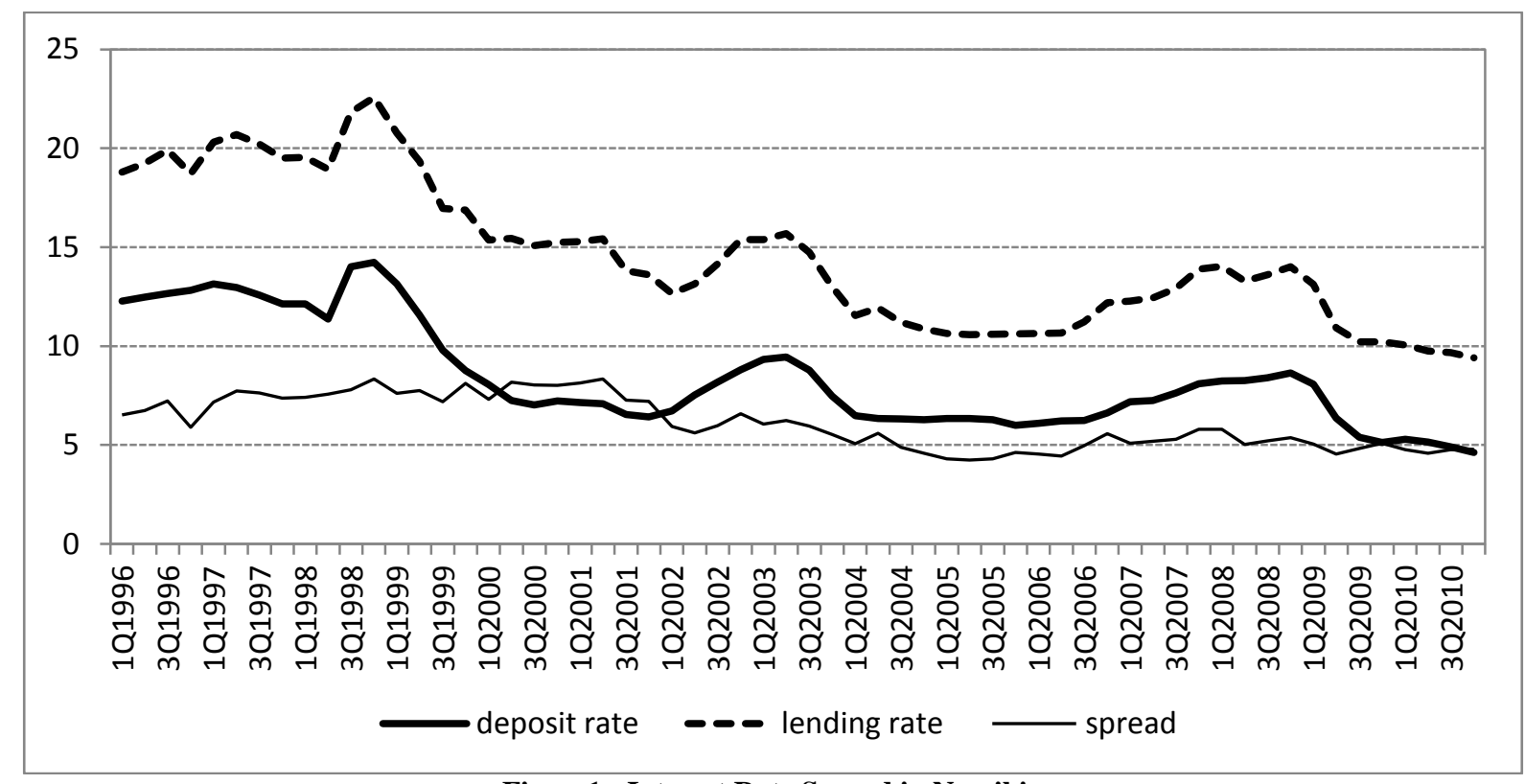

Figure1: Interest Rate Spread in Namibia

Source: Data for the graph obtained from Bank of Namibia. 


\section{BRIEF LITERATURE REVIEW ON DETERMINANTS OF INTEREST RATE SPREAD}

There is extensive literature on the determinants of interest rate spread. Some empirical studies classified determinants of interest rate into two categories - industry or market specific and macroeconomic determinants. Studies, such as Moore and Craigwell (2000), Brock and Suarez (2000), and Crowley (2007), stated that there are specific features of banks that, according to economic theory, are expected to have an impact on their interest rate spreads. These features include bank size, pattern of ownership, quality of the loan portfolio, capital adequacy ratio, overhead costs, lack of banking competition, lack of creditor rights, reserves and operating expenses. According to Crowley (2007), characteristics, such as lack of creditor rights, lack of banking competition, and increase in reserve requirements, are associated with an increase in interest rate spread. Banking concentration and tighter regulations are also associated with high interest rate spread.

A rise in operating costs and non-performing loans are associated with high interest rate spread. Banks charge higher interest rates in order to remain profitable. This was supported by Brock and Suarez (2000) who provided evidence that an increase in operating costs and non-performing loans results in a rise in interest rate spread. Increase in or higher reserve requirements and rising interest rates are associated with high interest rate spread (Gelos, 2006; and supported by Chirwa and Mlachila, 2004, regarding Malawi). The share of loans allocated to the public sector also has an impact. According to Randal (1998), an increase in the proportion of loans allocated to the public sector in Caribbean countries resulted in a decline in interest rate spread, which is attributable to the fact that greater involvement by the government causes large transactions that are efficient to manage.

Higher interest rate spread can also result from higher concentration in the banking sector. A reduction in banking sector competition can cause an increase in interest rate spread. However, Berger and Hannan (1989) argued that although greater concentration in the banking sector can lead to higher profits, it may not result in higher lending rates because a higher banking concentration can also cause efficiency. The size of the banking sector and economy can affect the competition. It is generally argued that smaller economies have greater concentration in the banking sector and a smaller number of banks. Despite that, Crowley (2007) stated that some small economies have very few large companies that represent reputable borrowers and banks compete vigorously to lend to them. According to Crowley (2007), the impact of a reduction of the economic size or the banking sector on interest rate spread can be negative if the small size causes a larger decrease in the number of reputable borrowers than in the number of banks. This suggests that the effect of economic or banking size on interest rate spread can be positive or negative.

Macroeconomic factors are also important in explaining variations in the interest rate spread. Empirical studies, such as Brock and Franken (2003) and Chirwa and Mlachila (2004), stated that macroeconomic instability and the economic policy environment have an important influence on interest rate spread. Macroeconomic variables that impact interest rate spread are inflation, output growth, treasury bills rate, money supply growth rate, exchange rate volatility, and the share of loans allocated to the public sector, among others.

Inflation represents the cost of doing business and is expected to have a positive impact on the interest rate spread (Chirwa and Mlachila, 2004). This argument is supported by Brock and Suarez (2000). However, Crowley (2007) argued that although higher inflation can cause higher inflation-adjusted interest rate spread if it causes banks to charge a risk premium, higher inflation resulted in a decrease of inflation-adjusted interest rate spread in Englishspeaking African countries. Despite that, Crowley (2007) supports the view that inflation rate is associated with an increase in interest rate spread.

The size of the economy (generally proxied by GDP) is another important determinant of interest rate spread. A bigger economy is expected to cause economies of scale and more competition. However, Crowley (2007) argues that it is possible for a larger economy to have more specialisation and financial markets which are deeper where borrowers that are risky can have more access to funds. In this case, a greater part of the banks' loans would be devoted to retail and specialised lending. Even if the lending rate does not change, the net interest income will be higher. According to Crowley (2007), this should be considered positive, rather than negative, development. Many economies that are small tend to be dominated by large state-owned banks which do not operate subject to strict profit constraint, in many cases, and are likely to have lower interest rate spreads. 
The Treasury bill rate has also been cited as a determinant of interest rate spread. It serves as an indicator of the interest rate policy pursued by the government and also serves as a benchmark for interest rates charged by commercial banks. According to Folaweo and Tennant (2008), the Treasury bill rate is expected to positively influence the interest rate spread - a lower Treasury bill rate will cause interest rate spread to decrease, while a higher interest rate causes the interest rate spread to increase. Government has an impact on interest rate spread through its fiscal policy. An increase in budget deficit, as a ratio of GDP, results in a rise in interest rate spread.

Interest rate spread will rise if the ratio of broad money to GDP increases. The ratio of broad money supply to GDP, or M2/GDP, is regarded as a measure of the impact of monetary aggregate on interest rate spread (Folawewo and Tennant, 2008). M2/GDP can be expected to have a positive (Folawewo and Tennant, 2008) or negative impact (Crowley, 2007) on interest rate spread. Exchange rate volatility is another variable that can influence interest rate spread. It is an indicator of macroeconomic instability. Increase in exchange rate volatility presents a risk to commercial banks and is expected to have a positive effect on interest rate spread. That is because commercial banks will increase the gap between lending and deposit rates in order to cover themselves against risks.

Finally, the discount rate also has an effect on the interest rate spread. This variable is regarded as a measure of the cost to commercial banks when they borrow from the central banks. This variable is no longer popular, but Folawewo and Tennant (2008) argued that it is still used by many countries as an important component of monetary policy. An increase in the discount rate is a reflection that the costs of commercial banks are rising, which will be transferred to customers through higher interest rate spread. The discount rate is therefore expected to have a positive effect on interest rate spread.

\section{EMPIRICAL MODEL, DATA AND METHODOLOGY}

\section{Empirical Model}

Following a review of the literature, the interest rate spread empirical model is specified as follows:

$$
S_{t}=\alpha_{0}+\alpha_{1} F D_{t}+\alpha_{2} G D P_{t}+\alpha_{3} P_{t}+\alpha_{4} E X V O L_{t}+\alpha_{5} \text { TBIL }_{t}+\alpha_{6} B_{R A T E}+\alpha_{7} M 2 G D P_{t}+\mu_{t}
$$

where $S, F D, G D P, P, E X V O L, T B I L, B R A T E, M 2 G D P$ are interest rate spread, financial deepening, GDP, inflation, exchange rate volatility, treasury bill rate, bank rate (discount rate), ratio of broad money, or M2 to GDP. The coefficients $\left(\alpha_{1}, \alpha_{2}, \alpha_{7}\right)$ are expected to be positive or negative, suggesting their signs are ambiguous. The remaining coefficients $\left(\alpha_{3}, \alpha_{4}, \alpha_{5}, \alpha_{6}\right)$ are expected to be positive. Equation (1) consists of market and macroeconomic determinants of the interest rate spread.

\section{Data}

Quarterly data are used and the estimation covers the period 1996-2010. Interest rate differential $(S)$ is computed as lending minus deposit rate. Exchange rate volatility is computed using the Hodrick-Prescott filter. The variable GDP represents the size of the economy. Financial deepening is computed as credit extended to the private sector as a ratio of GDP. Consumer price index represents inflation rate. The data are sourced from the Bank of Namibia and International Financial Statistics of the IMF. This study acknowledges that there are other important variables that are not included in Equation (1) because of unavailability of consistent time-series data, especially for industry and microeconomic data.

\section{Methodology}

Time series properties of the variables which involve unit root tests need to be established before the estimation of Equation (1). This study uses Augmented Dickey Fuller (ADF) test statistic in order to determine whether the variables to be used in the estimation have unit root. 
This study applies the vector autoregression (VAR) method. This model has advantages in the sense that time series can be modelled simultaneously. It corrects for autocorrelation and endogeneity parametrically using vector error correction model (VECM) specification. This method prevents substantial bias which takes place in OLS estimates of cointegration relations under the Engle-Granger two-step technique (Johansen, 1988; 1995). The Johansen econometric methodology is defined below. The starting point in VAR of order $k$ is given by:

$y_{t}=\mu+A_{1} z_{t-1}+\ldots \ldots . . A_{k} z_{t-k}+v_{t}$

where $y_{t}$ is $(n \times 1)$ vector of variables, each of $A_{i}$ is an $(n \times n)$ matrix of parameters, $v_{t}$ is a residuals or $(n \times l)$ vector of innovations. This type of modelling estimates the dynamic relationships among variables which are jointly endogenous without the imposition of strong a priori restrictions (Sims, 1980). This argument is supported by Harris (1995). Equation (2) can be re-written in a vector error correction model (VECM) format as:

$\Delta y_{t}=\mu+\prod y_{t-1}+\sum_{j=1}^{k-1} \Gamma_{i} \Delta y_{t-i}+v_{t}$

where $\prod=\sum_{i=1}^{k} A_{i}-I$ and $\Gamma_{i}=-\sum_{j=i+1}^{k} A_{j}$.

Equation (3) is assumed to consist of only $\mathrm{I}(0)$ variables and is a white noise because the terms in Equation (2) are all I(1). Harris (1995) states that this way of expressing the system will allow information on the short-run and long-run adjustments to changes in $y_{t}$ through $\prod$ and $\Gamma_{i}$ estimates. In the analysis of VAR, $\prod$ is a vector representing a matrix of long-run coefficients, which is very important in the analysis of VAR. The long-run coefficients are defined as multiple of two $(n \times r)$ vectors, $\alpha$ and $\beta^{\prime}$ (Eita and Jordaan, 2010). $\prod=\alpha \beta^{\prime}$, where the elements of $\alpha$ are called adjustment parameters in the VECM. They are loading matrices and denote the speed of adjustment to equilibrium. The elements of $\beta^{\prime}$ are a matrix of long-run equilibrium, such that the term $\beta^{\prime} y_{t}$ in Equation (3) represents up to $n-1$ economic equilibrium or cointergrating relationships in the model. If the $\prod$ has rank of zero, it indicates that the variables in $y_{t}$ are not cointegrated. If the rank is $r$ (number of cointegrating vectors), there will be $r$ possible stationary relationships. If the matrix has a full rank, the rank is $r=n$ and it suggests that there are $n$ cointegrating vectors and all variables in the equation are $\mathrm{I}(0)$. Cointegration is tested using two likelihood ratio test statistics. These test statistics are trace and maximum eigenvalue.

\section{ESTIMATION RESULTS}

\section{Unit Root Test Results}

The results for unit root test are presented in Table 1 which shows that all variables have unit root in levels (except exchange rate volatility and GDP). This means that they nonstationary in first difference. They become stationary on first difference.

\section{Cointegration Test and VECM Results}

Since the variables are I(1), it is important to test if they are cointegrated. Cointegration between the variables in Equation (1) is tested using Johansen's trace maximum eigenvalue statistics. The results are presented in Table 2. The results of the cointegration test in the table show that there is one cointegrating vector. Both the trace ( $\lambda_{\text {trace }}$ ) and maximum eigenvalue ( $\lambda_{\max }$ ) statistics show that there is one cointegrating vector. Since the variables are cointegrated, it is now appropriate to proceed to the vector error correction model (VECM). 
Table 1: Unit Root Test Results

\begin{tabular}{|c|c|c|c|}
\hline & & Levels & First Difference \\
\hline Variable & Model & ADF & ADF \\
\hline$S_{t}$ & $\begin{array}{l}\text { Constant } \\
\text { Constant \& trend } \\
\text { none }\end{array}$ & $\begin{array}{l}-1.36 \\
-2.88 \\
-0.71 \\
\end{array}$ & $\begin{array}{l}-9.98 * * * \\
-9.91 * * * \\
-10.01 * * * \\
\end{array}$ \\
\hline$T B I L_{t}$ & $\begin{array}{l}\text { Constant } \\
\text { Constant \& trend } \\
\text { none }\end{array}$ & $\begin{array}{l}-1.32 \\
-2.98 \\
-1.41 \\
\end{array}$ & $\begin{array}{l}-5.87 * * * \\
-5.81 * * * \\
-5.77 * * * \\
\end{array}$ \\
\hline$F D_{t}$ & $\begin{array}{l}\text { Constant } \\
\text { Constant \& trend } \\
\text { none }\end{array}$ & $\begin{array}{l}-0.64 \\
-2.31 \\
8.12 \\
\end{array}$ & $\begin{array}{l}-12.06 * * * \\
-11.97 * * * \\
-0.75\end{array}$ \\
\hline$E X V O L_{t}$ & $\begin{array}{l}\text { Constant } \\
\text { Constant \& trend } \\
\text { none }\end{array}$ & $\begin{array}{l}-2.98 * * \\
-2.94 \\
-3.01 * * *\end{array}$ & $\begin{array}{l}-6.08 * * * \\
-6.03 * * * \\
-6.13 * * * \\
\end{array}$ \\
\hline$G D P_{t}$ & $\begin{array}{l}\text { Constant } \\
\text { Constant \& trend } \\
\text { none }\end{array}$ & $\begin{array}{l}-1.02 \\
-3.30 * \\
4.80\end{array}$ & $\begin{array}{l}-11.23 * * * \\
-11.20 * * * \\
-1.44 * * *\end{array}$ \\
\hline$B R A T E_{t}$ & $\begin{array}{l}\text { Constant } \\
\text { Constant \& trend } \\
\text { none }\end{array}$ & $\begin{array}{l}-1.71 \\
-2.98 \\
-1.48 \\
\end{array}$ & $\begin{array}{l}-4.85 * * * \\
-4.81 * * * \\
-4.76 * * *\end{array}$ \\
\hline$M 2 G D P_{t}$ & $\begin{array}{l}\text { Constant } \\
\text { Constant \& trend } \\
\text { none }\end{array}$ & $\begin{array}{l}-0.52 \\
-2.99 \\
1.20 \\
\end{array}$ & $\begin{array}{l}-10.74 * * * \\
-10.70 * * * \\
-10.63 * * *\end{array}$ \\
\hline
\end{tabular}

Note: $* * * / * * / *$ indicate rejection of the hypothesis of nonstationary (there is unit root) at $1 \% / 5 \% / 10 \%$ significance levels, respectively.

Table 2: Cointegration Test Results

\begin{tabular}{|c|c|c|c|c|c|c|c|}
\hline \multicolumn{3}{|c|}{ Trace Test } & \multicolumn{5}{c|}{ Maximum Eigenvalue Test } \\
\hline$H_{0}$ & $H_{a}$ & $\lambda_{\text {trace }}$ & $\mathbf{5 \%}$ Critical Value & $H_{0}$ & $H_{a}$ & $\lambda_{\max }$ & $\mathbf{5 \%}$ Critical Value \\
\hline $\mathrm{r}=0$ & $\mathrm{r} \geq 0$ & $132.42^{*}$ & 111.78 & $\mathrm{r}=0$ & $\mathrm{r}=1$ & $48.92^{*}$ & 42.77 \\
\hline $\mathrm{r} \leq 1$ & $\mathrm{r} \geq 1$ & 83.50 & 83.93 & $\mathrm{r}=1$ & $\mathrm{r}=2$ & 29.66 & 36.63 \\
\hline $\mathrm{r} \leq 2$ & $\mathrm{r} \geq 2$ & 53.84 & 60.06 & $\mathrm{r}=2$ & $\mathrm{r}=3$ & 20.49 & 30.44 \\
\hline $\mathrm{r} \leq 3$ & $\mathrm{r} \geq 3$ & 33.35 & 40.17 & $\mathrm{r}=3$ & $\mathrm{r}=4$ & 15.35 & 24.16 \\
\hline $\mathrm{r} \leq 4$ & $\mathrm{r} \geq 4$ & 18.00 & 24.28 & $\mathrm{r}=4$ & $\mathrm{r}=5$ & 12.29 & 17.80 \\
\hline $\mathrm{r} \leq 5$ & $\mathrm{r} \geq 5$ & 5.71 & 12.32 & $\mathrm{r}=5$ & $\mathrm{r}=6$ & 5.69 & 11.22 \\
\hline $\mathrm{r} \leq 6$ & $\mathrm{r} \geq 6$ & 0.02 & 4.13 & $\mathrm{r}=6$ & $\mathrm{r}=7$ & 0.02 & 4.13 \\
\hline $\mathrm{N}$
\end{tabular}

Note: *Denotes rejection of the null of no cointegration at $5 \%$ significant level.

Since there is one cointegrating vector, the VECM is visualised as shown in Equation (4).

$$
\Pi y_{t-1}=\alpha \beta^{\prime} y_{t-1}=\left[\begin{array}{ll}
\alpha_{11} & \alpha_{12} \\
\alpha_{21} & \alpha_{22} \\
\alpha_{31} & \alpha_{32} \\
\alpha_{41} & \alpha_{42} \\
\alpha_{51} & \alpha_{52} \\
\alpha_{61} & \alpha_{62} \\
\alpha_{71} & \alpha_{72}
\end{array}\right]\left[\begin{array}{lllllll}
\beta_{11} & \beta_{21} & \beta_{31} & \beta_{41} & \beta_{51} & \beta_{61} & \beta_{71}
\end{array}\right]\left[\begin{array}{l}
S_{t-1} \\
F D_{t-1} \\
T L_{t-1} \\
G D P_{t-1} \\
P_{t-1} \\
\text { BRATE }_{t-1} \\
\text { EXVOL }_{t-1}
\end{array}\right]
$$

The long-run and short-run results are presented in Table 3. 
Table 3: VECM Results (Long-run and Short-run)

\begin{tabular}{|c|c|c|c|c|c|c|c|}
\hline \multicolumn{8}{|c|}{ Likelihood Ratio Test for Binding Restrictions (Rank = 1): } \\
\hline Chi-square(3) & 4.344378 & & & & & & \\
\hline Probability & 0.226599 & & & & & & \\
\hline Cointegrating Equation: & CointegratingEquation 1 & & & & & & \\
\hline $\mathrm{S}(-1)$ & 1.00 & & & & & & \\
\hline \multirow[t]{2}{*}{ TBIL(-1) } & -1.33 & & & & & & \\
\hline & {$[-2.03]$} & & & & & & \\
\hline \multirow[t]{2}{*}{$\mathrm{FD}(-1)$} & 2.76 & & & & & & \\
\hline & {$[2.53]$} & & & & & & \\
\hline \multirow[t]{2}{*}{ GDP(-1) } & 11.78 & & & & & & \\
\hline & [3.02] & & & & & & \\
\hline \multirow[t]{2}{*}{$\mathrm{P}(-1)$} & -2.34 & & & & & & \\
\hline & {$[-2.96]$} & & & & & & \\
\hline \multirow[t]{2}{*}{ BRATE(-1) } & -1.79 & & & & & & \\
\hline & {$[-1.77]$} & & & & & & \\
\hline \multirow[t]{2}{*}{ EXVOL(-1) } & 0.68 & & & & & & \\
\hline & {$[5.80]$} & & & & & & \\
\hline Error Correction Model: & $\mathbf{D}(\mathbf{S})$ & $\mathrm{D}(\mathrm{TBIL})$ & $\mathrm{D}(\mathrm{FD})$ & $\mathrm{D}(\mathrm{GDP})$ & $\mathrm{D}(\mathrm{P})$ & D(BRATE) & $\mathrm{D}(\mathrm{EXVOL})$ \\
\hline \multirow[t]{2}{*}{ Cointegrating Equation 1} & -0.04 & 0.00 & 0.02 & 0.00 & 0.01 & 0.00 & -0.03 \\
\hline & {$[-2.85]$} & {$[0.00]$} & [3.32] & {$[0.00]$} & [5.29] & {$[0.00]$} & {$[-1.83]$} \\
\hline
\end{tabular}

The first section of Table 3 contains the long-run results, while the lower section represents the short-run results. The long-run results show that increases in Treasury bill rate, bank rate, and inflation rate are associated with an increase in interest rate spread. A $1 \%$ increase in the Treasury bill rate causes interest rate spread to increase by $1.33 \%$. If the inflation rate increases by $1 \%$, interest rate spread would increase by $2.34 \%$. A $1 \%$ increase in bank rate (discount rate) causes interest rate spread to increase by $1.79 \%$.

An increase in the size of the economy (proxied by GDP) and financial deepening or development is associated with a decrease in interest rate spread. A $1 \%$ increase in GDP results in a decrease in interest rate by $11.78 \%$, while an increase in financial deepening by $1 \%$ causes interest rate spread to decline by $2.76 \%$. Exchange rate volatility causes interest rate spread to increase, which is contrary to theoretical expectation.

The second section of Table 3 presents the estimated loading matrices or $\alpha$ coefficients. These coefficients indicate whether the variable in question plays a role in bringing the dependent variable to equilibrium. If a variable has an adjustment coefficient of 0 , it suggests that the variable in question does not play a role in bringing the normalised variable to equilibrium. The loading matrices relate to weak exogeneity issue. A variable that does not play a role in bringing the dependent variable to equilibrium is weakly exogenous. The results in the second section of Table 3 show that the coefficient of the error correction model (interest rate spread) is negative and statistically significant. Interest rate spread plays a role in bringing itself to equilibrium. Exchange rate volatility also plays a role in bringing interest rate spread to equilibrium. Financial development or deepening and inflation rate moves the interest rate spread away from equilibrium. Treasury bill rate, size of the economy (GDP), and inflation rate are weakly exogenous. They do not play a role in bringing the interest rate spread to equilibrium in the short run. The likelihood ratio shown in the top section of Table 3 fails to reject the imposed restriction which means that they (restrictions) are binding.

\section{CONCLUSION}

This paper investigated the determinants on interest rate spread in Namibia for the period 1996-2010 using quarterly data. The investigation revealed that the interest rate spread in Namibia is determined by Treasury bill rate, financial development or deepening, the size of the economy, inflation rate, the bank rate (discount rate), and exchange rate volatility. The study acknowledges that there are other important variables in the determination of interest rate spread, but they were not included in the estimation due to lack of consistent time series data.

The results indicate that Treasury bill rate, inflation rate, and bank rate are associated with an increase in interest rate spread. An increasing Treasury bill rate indicates the interest rate policy pursued by the government. If 
the government pursues a high interest rate policy, it sets the benchmark for commercial banks and will cause interest rate spread to increase. The positive effect of inflation rate on interest rate spread suggests that a higher inflation rate increases the risk premium that banks need to charge, which results in higher interest rate spread. The positive effect of the bank rate indicates that as the cost of funds for commercial banks increases, it may be passed on to consumers by means of higher interest rate spread.

The results also indicate that increases in the size of economy, financial deepening or development cause interest rate spread to decrease. The negative effect of the size of the economy on interest rate spread suggests an increasing size of the Namibian economy allows for economies of scale and greater competition, which reduces the interest rate spread. It reflects the level of economic development and technology and a mix of banking opportunities. Hence, interest rate will decrease. The negative of financial deepening suggests that as the level of financial development improves, the level of competition between banks increases. The interest rate spread will then decrease.

\section{AUTHOR INFORMATION}

Joel Hinaunye Eita, Ph.D. is an Associate Professor of economics at Monash University. His research interests include international trade and finance, financial and monetary economics, time series econometrics, macroeconometric modelling and panel data econometrics. He published in local and international journals. E-mail: joel.eita@monash.edu or hinaeita@yahoo.co.uk.

\section{REFERENCES}

1. Barajas, A., R., Steiner, R. and Salazar, N. (2000). Interest Spreads in Banking in Colombia, 1974 -96. IMF Staff Papers, 46, 196-224.

2. Berger, A.N., and Hannan, T.H. (1989). The Price-Concentration Relationship in Banking. Review of Economics and Statistics, 71(2) 291 -299.

3. Brock, P. and Franken, H. (2003). Measuring the Determinants of Average and Marginal Bank Interest Rate Spreads in Chile, 1994 -2001. Retrieved from: http://www.econ.washington.edu/user/plbrock/ChileSpreads091603.pdf.

4. $\quad$ Brock, P.L., and Suarez, L.R., (2000). Understanding the Behaviour of Bank Spreads in Latin America. Journal of Development Economics, 63, 113-134.

5. Calderon, C. and Liu, L. (2003). The Direction of Causality Between Financial Development and Economic Growth. Journal of Development Economics, 72, 321-334.

6. Chirwa, E.W., and Mlachila, M. (2004). Financial Reforms and Interest Rate Spreads in the Commercial Banking System in Malawi. IMF Staff Papers, 51(1) 96 - 122.

7. Choe, C. and Moosa, I.A. (1999). Financial System and Economic Growth: The Korean Experience. World Development, 27(6) 1069-1082.

8. Crowley, J. (2007). Interest Rate Spreads in English-Speaking African Countries. IMF Working Paper, P/07/101, International Monetary Fund, Washington D.C.

9. Eita, J.H. and Jordaan, A.C. (2010). A Causality Analysis Between Financial Development and Economic Growth for Botswana. African Finance Journal, 12(1) 74-89.

10. Folawewo, A.O. and Tennant, D. (2008). Determinants of Interest Rate Spreads in Sub-Saharan African Countries: A Dynamic Panel Data Analysis. Paper Presented at the $13^{\text {th }}$ African Econometric Society Conference, Pretoria, South Africa, 9-11 July.

11. Gelos, R. (2006). Banking Spreads in Latin America. IMF Working Paper, WP/06/44, Washington D.C.

12. Harris, R.I.D. (1995). Using Cointegration Analysis in Econometric Modelling. London, Prentice Hall/Harvester Wheatsheaf.

13. Johansen, S. (1988). Statistical Analysis of Cointegrating Vectors. Journal of Economic Dynamic and Control, 12, 231-254.

14. Johansen, S. (1995): Likelihood Based Inferences in Cointegrated Vector Autoregressive Models. Oxford: Oxford University Press.

15. Jung, W.S. (1986). Financial Development and Economic Growth: International Evidence. Economic Development and Cultural Change, 34, 334-346. 
16. Levine, R. (1997). Financial Development and Economic Growth: Views and Agenda. Journal of Economic Literature, 35(2) 688-726.

17. McKinnon, R.I. (1973). Money and Capital in Economic Development. Washington, The Brooking Institution.

18. Moore, W. and Craigwell, R.W. (2000). Market Power and Interest Rate Spreads in the Carribean. Paper Presented at the XXXII Annual Monetary Studies Conference, Kingston, Jamaica, 5 November.

19. Ndung'u, N. and Ngugi, R.W. (2000). Banking Sector Interest Rate Spreads in Kenya. Kenya Institute of Public Policy Research and Analysis Discussion Paper, No. 5, Nairobi, Kenya.

20. Randall, R. (1998). Interest Rate Spreads in the Eastern Caribbean. IMF Working Paper, WP/98/59.

21. Shaw, E.M. (1973). Financial Deepening in Economic Development. Oxford, Oxford University Press.

22. Sims, C. (1980). Macroeconomics and Reality. Econometrica, 48(1) 1-48. 


\section{NOTES}

